\title{
Conduct Pragmatism: Pressing Beyond Experientialism and Lingualism
}

\section{Colin Koopman}

\section{OpenEdition}

\section{Journals}

\section{Electronic version}

URL: http://journals.openedition.org/ejpap/313

DOI: 10.4000/ejpap.313

ISSN: 2036-4091

\section{Publisher}

Associazione Pragma

\section{Electronic reference}

Colin Koopman, «Conduct Pragmatism: Pressing Beyond Experientialism and Lingualism », European Journal of Pragmatism and American Philosophy [Online], VI-2 | 2014, Online since 24 December 2014, connection on 19 April 2019. URL : http://journals.openedition.org/ejpap/313; DOI : 10.4000/ ejpap.313

\section{(c) $($ ) $(9)$}

Author retains copyright and grants the European Journal of Pragmatism and American Philosophy right of first publication with the work simultaneously licensed under a Creative Commons AttributionNonCommercial-NoDerivatives 4.0 International License. 


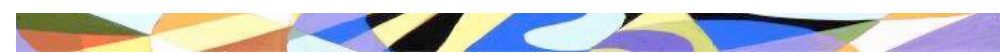

EUROPEAN JOURNAL OF PRAGMATISM AND AMERICAN PHILOSOPHY

COPYRIGHT C 2009 ASSOCIAZIONE PRAGMA

Colin Koopman*

Conduct Pragmatism: Pressing Beyond Experientialism and Lingualism

Abstract: Debates over the relative priority of experience and language have been among some of the most vexed, but also generative, disputes in pragmatist philosophy over the past few decades. These debates have, however, run into the ground such that both positions find themselves at a definitive standstill. I argue for a rejuvenation of pragmatism by way of moving beyond both the experience option (here represented by Dewey) and the linguistic turn in pragmatism (here represented by Brandom). We can move beyond these two categories, I argue, by resuscitating the categorical conception that has always been at the heart of pragmatism all along: action or, as I prefer to put it, conduct. In this paper, I develop an argument for "conduct pragmatism" on the basis of a return to William James's earliest statements of pragmatism, statements that indeed occur prior to the official announcement of "pragmatism" in 1898. I draw on a dispute with Charles Sanders Peirce over the best interpretation of pragmatism as well as on a number of James's early psychological writings from the 1880s leading up to the Principles of Psychology of 1890. These texts definitively establish that the early James was what I call a "conduct pragmatist" well before his radical empiricism facilitated what was only a late turn toward the "experience pragmatism" that would come to impress Dewey and later scholars of classicopragmatism. The early James thus represents, I argue, a promising seed for a new third generation of pragmatism that may find its way beyond the endings of both experientialism and lingualism, as well as their impasses with one another.

\section{In Want of a Contemporary Pragmatism}

There is in contemporary pragmatism a decisive want, in the older sense of that term more common to our inherited nineteenth-century than our contemporary twentyfirst-century usages of English. What is wanted is a conception of pragmatism that fully acknowledges the widespread dissatisfactions with the two dominant categories that came to form a core dilemma for almost every major tradition in twentiethcentury philosophy: the categories of experience and language. What is wanted is the work of pressing pragmatism toward its next moment where it would be, perhaps, finally beyond the dilemmas these categories impose. This would require nothing less than a renewal of a pragmatism that readily accepts the deficiencies that have come to dominate our received categories and works to rectify their shortcomings. Richard J. Bernstein rightly argues that the "apparently well-entrenched dichotomy between experience and the linguistic turn is just the sort of dichotomy that pragmatists ought to reject" ${ }^{\prime}$. Rejecting this dichotomy from a pragmatist vantage, I shall argue, must involve allowing, and even cultivating, forms of pragmatism that are neither experience-centric (experientialist) nor language-centric (lingualist). It is in this sense that pragmatism today is in want of a new center.

\footnotetext{
* University of Oregon [cwkoopman@gmail.com]
}

1. Bernstein (2010: 128). 
Why, we could ask, all the clinging to the over-freighted categories of experience and language? Why, we might wonder, does pragmatism refuse, time and again, to accept that these former options have grown exhausted? But I shall not here press for explanations of the entrenchment of the experientialist and lingualist perspectives. Rather, I shall press forward toward that which might fulfill the want of pragmatism. Searching beyond experience and language, the history of pragmatism presents a third option which I propose to here begin the work of excavating. I refer to this third option as conduct pragmatism. At the center of this option is a species of pragmatism that revolves around a (re-)new(-ed) constellation of categories: conduct, action, practice, habit, and will. This constellation, I argue, helps pragmatism press further than do the currently-prominent centering notions of experience and language. To be sure, however, pragmatism in its first two waves indeed offers formulations of experience and language that do invoke conceptions of conduct. Thus my claim could be read as simply a call to play up conduct-centering notions of experience and language. I suspect, though, that there will be considerable resistance to this from some contemporary pragmatists. For playing up conduct requires playing down formulations of experiential and linguistic pragmatism that fail to focus those notions in terms of conduct.

In developing conduct pragmatism, there is no need to deny experience and language their place. All that I propose is to shift the center of pragmatism's vision. The categories of experience and language loomed large in early-twentieth and latetwentieth century pragmatism respectively (as well as in philosophy more generally as suggested by the examples of other such traditions as analytic philosophy, phenomenology, and critical theory). Thus while there is no doubt that experience and language have some role to play in the continuation of pragmatism, I aim to encourage a toning down of the obsession that too often characterizes our fidelity to (one or the other of) these categories. These categories are in need of a decisive decentering. For, as I have argued elsewhere, both Dewey and the later James massively overplayed their hands with their attachment to a metaphysics of experience, and Brandom and much of Rorty seriously overcommitted themselves to the restrictive strictures of the linguistic turn - what is most successful in the work of all four is an emphasis on the dynamic and processual aspects of practice, experience, and language, but this transitional quality of pragmatism too often gets lost in a fidelity to experience or language ${ }^{2}$. Acknowledging these commonly diagnosed deficits in the history of a tradition of thought that nonetheless furnishes a massive embarrassment of riches might require a new focus, at least for awhile. If I am right that process and transition are among the key insights of pragmatism, then a renewed focus on a bloomingly processual notion like conduct seems a much better promise for pragmatism today than a continuation of the thankless labor of foisting processual interpretations on categories of experience and language that continually buckle under such hermeneutic insistence. I am urging that we trade in our anxieties over experience and language so that we may attend to that which may have always been the central term in pragmatism anyway: action, or conduct.

2. See Koopman (2009: 72-107). 
There are precedents for my approach in some of the most recent interventions in contemporary pragmatism's experience-versus-language debates ${ }^{3}$. Consider as just one example how literary theorist Paul Grimstad has developed an insightful argument for the work of composition as the best path forward for contemporary pragmatism. Grimstad's Experience and Experimental Writing: Literary Pragmatism from Emerson to the Jameses returns the reader to absorbing scenes of experimental literary production in mid-to-late nineteenth-century arts and letters in order to mount an argument concerning the options available to we contemporary pragmatists ${ }^{4}$. Grimstad's argument is important because it is decisively situated at the centerpoint of our contemporary debate. Reviewing the crux of the issue between classicopragmatist experientialisms and recent neopragmatist lingualisms, Grimstad makes a bid for what we might call (not his term) a post-lingualist-experientialism. It is crucial that this position is beyond both second-generation lingualism and first-wave experientialism. It is, to be sure, a return to the privileged scene of classicopragmatism, but only as absorbable through the insights of neopragmatism. This, I would argue, is quite close to fulfilling the desiderata I am attributing to contemporary pragmatism. Grimstad's gain is that he, unlike so many who would reiterate the same positions within either experience-centric or language-centric pragmatism, seeks to absorb the insights of both in order to develop some third. He does so, quite provocatively, by making use of the daring work of Stanley Cavell: "With the analytic [neo]pragmatists' sensitivity to the myth of the given in mind, I want to return to Cavell's description of composition as an experimental search, with the aim of finding in it an account of meaning that would be sensitive to the tension between the 'given' and linguistic meaning, yet not reduce meaning simply to a matter of justification"5. Grimstad here calls for exactly what we require in the present moment: a restatement of pragmatism that is both hypersensitive to neopragmatist concerns and also rapt with classicopragmatist achievements ${ }^{6}$.

If those of us who are sensitive to both classicopragmatism and neopragmatism are not unbalanced by our double vision, as some would assert, then we are right

3. In addition to Grimstad's contributions in literary theory discussed here, see also important recent work in philosophy by contemporary European pragmatists Stephane Madelrieux (2012) and Sarin Marchetti (2012). I of course place no weight on a distinction between philosophy and literary theory, seeing them rather as mostly continuous.

4. Grimstad 2010.

5. Grimstad (2013: 10).

6. Grimstad, unfortunately, claims to meet these desiderata by way of a retrieval of composition that is itself cast in terms of a classicopragmatist conception of experience as process $(2013: 1,13,120)$. This is by now a standard move - it is also pursued, for instance, by Bernstein (2010: 128) and in a way in some of my own earlier work in Koopman (2007). In contrast to this work, my argument is that a return to experience is hardly the most fecund path forward for pragmatism today. Fortunately, neither is such a return the primary lesson that Grimstad's work teaches. For the important thing about composition is not that it experiential (as Grimstad wants to claim) nor that it is linguistic (as some others could conceivably claim), but rather that it is active. Composition is a species of conduct. Composition is an act. When a writer, a musician, a painter, or a dancer composes, they are doing something. This act of composition, interestingly, produces as the yield of its process a product that goes by the same name as the process. What I am suggesting, then, is that we follow the contours of Grimstad's analysis rather than his self-interpretation of where that analysis should lead us. If we do so, we find in Grimstad's conception of composition a gesture that very much anticipates what we, today, are definitively in want of. 
to want from contemporary pragmatism some new focal point toward which we could find ourselves not looking askance. Satisfying this want requires the activity of pressing pragmatism forward. Pressing pragmatism toward its next generation (in the sense of that which pragmatism will itself generate) will involve a double task of both excavating that which is a resource within the tradition and renewing such resources as they are extracted midst contemporary problematics. In developing a version of third wave pragmatism focusing specifically on conduct, I shall here focus on just the first of these two tasks (though I shall along the way offer a few suggestions about the latter, pointing there to what I regard as companion work that is already underway). I shall undertake this first task by way of excavating from the early (by which I mean pre-1897) writings of William James a version of conduct pragmatism that has gone largely unnoticed in standard histories of pragmatism, clouded over as they have been by an obsession with the later (post-1896) Jamesian program of a radically empiricist metaphysics of experience. In excavating conduct pragmatism in the early writings of James I shall also have occasion to suggest what advantages it might offer to us today. Before turning to James, however, I shall begin by further motivating what I have so far merely claimed above regarding the discontent that is widely felt with respect to the still-resident options of experience pragmatism and language pragmatism ( $\S$ IIIV). After developing those doubts I shall go on to offer a suggestion as to how a contemporary renewal of an early Jamesian version of nineteenth-century pragmatism, prior to twentieth-century experiential and linguistic turns, may hold out promise as a renewing starting point for us today $(\S \mathrm{V})$.

\section{Criticisms of First- and Second-Wave Pragmatisms}

One central task of pragmatism of any variety is to articulate an account of normativity without foundations ${ }^{7}$. There are, to be sure, other tasks on the pragmatist agenda, but no pragmatism can afford to shirk this central charge. My justification for this strong claim is the history of the pragmatist tradition itself. Every critical moment in the history of pragmatism has been structured by at least this demand (and probably others too).

Consider the common wisdom that pragmatism enacts a philosophical accommodation of a culture of both epistemic and political uncertainty ${ }^{8}$. This familiar observation about the loss of certainty as a negative condition for pragmatism can also be put positively in terms of a less customary account of pragmatism as an accommodation to the taming of chance and the emergence of probability ${ }^{9}$. One advantage of the alternative narrative focusing on the positive conditions of chance is that it brings into clearer view the dual task of pragmatism as I have stated it: anti-

7. See my argument in Koopman 2011.

8. Kloppenberg 1986.

9. Hacking (1990) offers a masterful narrative of the taming of chance in the nineteenth century, a narrative that ends with Peirce as a culminating figure; I take up Hacking's narrative in Koopman (unpublished-a) by focusing not on Peirce and the epistemic culture of chance but on James and the moral culture of chance. 
foundationalism plus anti-relativism. For one easy way to accommodate uncertainty is to mount an anti-foundationalist, anti-representationalist, and anti-absolutist offensive involving a lapse into relativism. But that is not pragmatism's pursuit. Accommodating a culture of uncertainty in the senses highlighted by ideas of chance, probability, and possibility involves not only an anti-foundationalist offensive but also the difficult task of working out an alternative account of normativity (in its dual senses of both epistemic correctness and moral rightness) that is no longer reliant on foundations.

It is rather easy to abandon foundations if one is willing to endorse relativism, just as it is easy to account for normativity if one is willing to suffer foundations. But those easy paths have proven themselves dead-ends: abdications of the severe work of philosophy rather than expressions of it. Pragmatisms of every variety thus pose for themselves a formidable but crucial philosophical challenge: normativity without foundations, or authority without authoritarianism.

Unfortunately, various iterations of pragmatism that are exemplary of the first two waves of the tradition have faltered in this task. The first wave of experientialist pragmatism failed to fully outflank foundationalism because it worked too hard to center pragmatism on a conception of experience that sought to be anti-foundationalist but could not achieve its own stated aim. The second wave of linguistic pragmatism has been nothing but hyper-anxious about foundationalism, and so has not failed on that score, but rather with respect to the other desiderata of offering a compelling account of normativity. Such an account has, to be sure, been an express aim of many offerings exemplary of second-wave neopragmatism, but these offerings have, I argue, so far failed to catch their target.

\section{The Criticism of Experientialist Pragmatism}

My argument is that the experience pragmatism featured in James's radical empiricism and Dewey's experiential instrumentalism, despite its enormous merits in other domains, is limited with respect to my central problem of pragmatist philosophy: accounting for normativity without recurring to foundations. The two signature moments in early-twentieth-century pragmatism to which we can pin the criticisms I develop below can be found in Dewey's metaphysics of experience and James's radical empiricist program. For reasons of space, I shall focus the present discussion solely on Dewey, returning later to James, albeit to a much earlier James. I leave to the side James's radical empiricism because I take it that James's work there fairly clearly falls afoul of the antifoundationalist strictures I detail below in the more complicated case of Dewey's instrumentalist empiricism ${ }^{10}$.

It is well known that neopragmatists have taken Dewey to task for his over-reliance on an unreconstructed (perhaps because unreconstructable) concept of experience. Rorty's criticisms are the best known ${ }^{11}$, but consider how Brandom puts the point:

10. See the latter chapters of James's A Pluralistic Universe (1910a) for where radical empiricism falls foul.

11. Rorty (1992: 295; 1977: 81). 
"Dewey expended a great deal of effort in the dual process of trying to make clear and get clear himself about how the norms and standards and what they are norms and standards for assessing jointly develop in the course of experience. I cannot say that it seems to me that he succeeded very well at either task"12. Brandom develops this (Rortyan) argument by way of a (Sellarsian) criticism of Dewey's experientialism according to which the latter commits what the former titled as the myth of the given (or what I like to call givenism) ${ }^{13}$. I do not think Brandom's development of his criticism holds at a textual level insofar as his claim is that Dewey posits the "satisfaction of a desire" as epistemically determinative ${ }^{14}$. This is decidedly not Dewey's view ${ }^{15}$.

Brandom nonetheless does make an important point that readers of Dewey ought not to treat too lightly. Consider Brandom's concern that Dewey frequently invokes a concept that he forces to play the double-role that Sellars criticized as givenness: "On the one hand, one is not supposed to need to have mastered concepts in order to be in this state [...] On the other hand, being in those states is supposed to count as knowing something, in the sense that it provides evidence for or against the truth of a belief" 16 . That just is givenism, which is for Brandom (following Rorty, following Sellars) rightly a sin insofar as it cannot but help extending an invitation to empiricist foundationalism. Brandom misattributes this double-role to Dewey in pinning it on his concept of felt desire satisfaction, but we can rightly attribute this double-role to Dewey's concept of felt qualitative immediacy, which is anyway far more central to his experientialist instrumentalism than desire ever was.

To see how the Sellarsian criticism sinks teeth into Dewey textually, consider Dewey's account of pervasive unifying quality, a signature notion found throughout much of his later work. In his 1938 masterwork Logic: The Theory of Inquiry Dewey conceptualized "immediately pervasive quality" as that in virtue of which a situation is taken in immediate experience as a situation and also as that which offers regulatory and controlling guidance within the situation ${ }^{17}$. In an important statement leading up to his Logic, Dewey's 1930 essay "On Qualitative Thought" poses what is perhaps his most pointed expression of the idea of qualitative control: "The underlying unity of qualitativeness regulates pertinence or relevancy and force of every distinction and relation; it guides selection and rejection and the manner of utilization of all explicit terms"18. Dewey's claim, in short, is that there is a "unity of qualitativeness" in every situation that "regulates" and "guides selection". Dewey repeated similar formulations

12. Brandom (2011: 20); for a statement indicating that exactly this was one thing he sought to get clear on see Dewey (1938: 13).

13. Brandom (2000b: 73); see also the argument as sketched in Brandom (2004: 51).

14. Brandom (2004: 51).

15. Interestingly, this is also the criticism that Russell (1940: $404 \mathrm{ff}$. as cited in Dewey (1941: 181)) offered against Dewey at one point, to which Dewey (1941) satisfactorily responded that the criticism is based on a misinterpretation. For responses to Brandom in textual defense of Dewey see Bernstein (2007: 103-4), Hickman 2007, Putnam 2009, and Beisecker unpublished. Levine (2012: 130, 136) helpfully points out that Brandom may have subsequently retreated from this more pointed criticism (in 2000b) to a broader criticism (in 2011) of the type that I pursue here.

16. Brandom (2000b: 73).

17. Dewey $1938: 73$; see the entirety of Chapter 4 for a rich discussion of this notion.

18. Dewey $1930: 247-8$. 
again in the $1938 \operatorname{Logic}^{19}$, and then again in a 1941 reply essay to critics where he wrote, "Inquiry begins in an indeterminate situation, and not only begins in it but is controlled by its specific qualitative nature" ${ }^{20}$. The gist of the idea can be traced back as far as Dewey's 1903 contributions to the Studies in Logical Theory, where he boldly proclaimed at the outset that, "it is the object of this chapter to present the problem and industry of reflective thought from the standpoint of naïve experience" 21 . Though it stretches back to 1903 and culminates in 1938, Dewey first consolidated these ideas in his 1925 Experience and Nature, where we find him writing of "the primacy and ultimacy of gross experience" and where he asserts of such experience that "all cognitive experience must start from and must terminate in being and having things in just such unique, irreparable and compelling ways"22.

Now, if the "qualitative nature" or "primary experience" that Dewey explicitly posited as "controlling" is indeed "naïve" or "gross" in the sense of an experience that is taken as felt and nonconceptual, then we have here a paradigmatic statement of givenism. And, in fact, it is precisely in terms of nonconceptual experience that Dewey consistently specified his idea of qualitative thought. In the 1930 essay he writes: "We are aware of it [i.e., quality] not by itself but as the background, the thread, and the directive clue in what we do expressly think of [...] It is felt rather than thought" 23 . That sounds to me about a striking a statement of the thought that quality is felt but not conceptual as one can imagine. This is a formulation that Dewey would repeat time and again in later writings, including Experience and Nature and Logic ${ }^{24}$.

From this we can conclude Dewey's explicit thematization of the regulatory and directive nature of the perceptual-but-nonconceptual arena of the qualitative just is an incipient form of empiricist givenism. Dewey's givenism is well summarized in his locution "qualitative control" which combines at once the two signature elements of the given: experiential feltness and normative regulation ${ }^{25}$. For these reasons, taking seriously Brandom's (and Rorty's) Sellarsian criticisms of classical pragmatism induces a shift of prioritization that breaks from an emphasis on qualitative experience in order to focus energy on other more fruitful aspects of the classical pragmatist $\operatorname{program}^{26}$.

19. Dewey there writes: "If the unique quality of the situation is had immediately, then there is something that regulates the selection and weighing of observed facts and their conceptual ordering" (1938 LW 12: 76), and "The universe of experience surrounds and regulates the universe of discourse but never appears as such within the latter" (1938: 74)

20. Dewey 1941: 181 .

21. Dewey (1903: 53).

22. Dewey 1925: 24, 378; the latter quote is from the 1925 first published version of the book's opening chapter, which was later revised by Dewey in the 1929 edition.

23. Dewey 1930: 248.

24. In the Logic the idea is stated thus: "the situation as a qualitative whole is sensed or felt [...] It is not, as such, an object in discourse" (1938: 73-74). In Experience and Nature Dewey even goes so far as to describe "irreducible [and] indescribable qualities" as "self-sufficient, wholly immediate, neither a relation nor an element in a relational whole" therein employing a formulation marking Dewey's then-massive distance from the Hegelian critiques of immediacy with which he began his philosophic career (1925: 74)

25. Dewey 1938: 218

26. At this point, it may be replied that Dewey's view is that felt quality is a kind of mediated 
It is crucial to underscore that the concerns I raise here warrant only a shift of prioritization - there is here no question of a full refutation of classical pragmatism. For it is undeniable that Dewey himself wrestled mightily with the problem I am articulating - and he is therefore a resource for us in similar pursuits today. Of "the given in the sense of the singular" Dewey claimed in the Logic that "it is taken rather than given" 27 . And whereas Experience and Nature located the "test" of ideas in "crude" primary experience, Dewey is more cautious in Quest for Certainty four years later where he explicitly states that "operations define and test the validity of the meanings by which we state natural happenings" 28 . One can find many other such formulations with the clear effect of an impression that Dewey sought at least sometimes to resist givenism. We should applaud this aspect of Dewey. But we need not commit ourselves to the devotional view that such occasional formulations from Dewey reach anything near the pitch of clarity that would only emerge with later pragmatisms developed by Sellars and Quine ${ }^{29}$. The problems with givenism are but dimly sensed in Dewey's early experientialist pragmatism. That Dewey fell into the snares of givenism diagnosed by later thinkers is not particularly surprising upon reflection if we consider that he articulated his experientialist programs well before Sellars, Quine, and others sniffed out some of the subtler difficulties haunting philosophical empiricism.

What is surprising, however, is the broad chorus of contemporary pragmatists who continue to draw on Dewey and James without reconstructing classicopragmatisms in light of neopragmatist criticisms. My point, of course, is not that this contemporary work is wrong. Rather, my concern is that the best of contemporary classicopragmatism

immediacy, perhaps both perceptual and conceptual, as argued by Shane Ralston (2013: 7). On this reading Dewey(ans) could avoid givenism and at the same time present a picture of experience as bearing on normative determination. But this evasion is open to the pragmatist only if they can offer an explanation of how concepts figure directly into experiences that are "immediate" in contrast to "mediate" and as "had" in contrast to "known". In other words, on the only interpretation that seems able to save Dewey from givenism, there is the difficulty of explicating how something can be both conceptual and not known, or what it means for experience (either taken holistically or in bits) to be "immediately conceptual" or "had as conceptual". While I find this an intriguing philosophical path, I do not see how Dewey's own writings bear up all that well under this reading. In a slightly different vein, and since Ralston's defense draws on (2013: 5-6) work by Mark Johnson (2007: 100), it is worth noting that in even more recent writings (2014: 100-102) Johnson offers an interesting defense of Dewey's idea of qualitative guidance against the kinds of concerns I raise here. Johnson responds to earlier versions of this worry as raised by Shusterman 2000 and in Koopman 2009. Johnson regards Dewey as showing that qualitative experience guides us from a problematic to a resolved situation. I agree with this insofar as it is compatible with the thought that experience itself does not always give the clue for automatically resolving the problematic, especially where we find ourselves in the face of conflicting moral values. Agreeing with this, however, I suspect there would still be disagreement between myself and most experientialist pragmatists with respect to just how far qualitative guidance concerning the problematicity or resolvedness of a situation takes us. I think it cannot take us very, such that almost all the difficult work is of the sort that will have to be hashed out on the level of ongoing conduct.

27. Dewey 1938: 127

28. Dewey 1929: 90n2 (though note that the more cautious formulation is buried away in an exegetica footnote).

29. Calling these figures pragmatists is of course contentious - for one recent precedent in favor see Misak 2013 and for a recent statement of the counter view see Burke 2013 
does itself a disservice by overextending its investments in experience. When this happens, what are otherwise brilliant insights of classicopragmatism get lost. To take just one example, I agree with David Hildebrand and Gregory Pappas that one signature advantage of classicopragmatism is its "insistence on the practical starting point" 30 . But I am puzzled about their claim that we must always specify the practical starting point in terms of a conception of "experience" that is assumed to always be "the best methodological starting point for a melioristic philosophy in a processual world" 31 . I take it to be a controversial issue whether or not a methodological prioritization of the category of experience is the best way of making sense of the pragmatist commitment to a practical starting point. My claim, developed below, is that conduct is more often a better starting point, and that experience ought to be pressed into service only to the extent that it actually illuminates practice. It might be thought that this is exactly what the experientialists are aiming for too, at least insofar as they can be read as suggesting that we ought to begin with experience in its active (but not passive) sense. Even on this view, however, there would still be an important site of disagreement: my claim is that experience matters only insofar as it illuminates practice such that practice could also gain illumination otherwise, whereas the experientialist view as it is often stated commits us to the claim that active experience is always the best way of illuminating action. But how could we possibly know that in advance? My argument begins with the claim that conduct or action is more intimate than experience with the "practice" that is rightly called for in pragmatism's "practical starting point". In that case, what matters in "active experience" is the "active" bit and not so much the "experience" part. For experience is methodologically dispensable should it turn out that we can gain focus on activity in some other way. And would the experientialists be willing to regard the experience part as dispensable? (I doubt it, but if so, then I welcome precisely that shift of attitude concerning experience.) For it is my view that experience (like everything else) must be dispensable if it should turn out that it does not feature in practice. This is why I would urge that experientialist pragmatisms could benefit from a fuller consideration of the advantages of the conduct option. Unfortunately, they have yet to do so, and in some cases they have even explicitly denied conduct its place in pragmatism, thus leading to the uncomfortable result of statements of pragmatism that expressly deny the import of action ${ }^{32}$.

30. Hildebrand and Pappas 2010. See further the elaboration of this idea in Hildebrand (2003: $6 \mathrm{ff}$., $70 \mathrm{ff}$., and $181 \mathrm{ff}$.) and Pappas (2008: 11 ff., 20 ff.).

31. Hildebrand and Pappas 2010. For this "experientialist" interpretation of the important pragmatist idea of a practical starting point (PSP) see further work by both. Hildebrand often treats the PSP as merely methodological (2003: 71) but also frequently interprets it as a necessarily experientialist method: "the PSP may designate or denote experience without first imputing a reflective characterization to it [and] this is the sense in which experience is method" (2003: 189). In more recent work, Hildebrand brings to a nub the problem I am here articulating, and this may be evidence of a nuancing of his earlier view (2011: 55, 58). Pappas, by contrast, seems to state the view even more strongly in his claim for, "a prereflective, qualitatively felt present situation as not only the starting point but the ultimate source of guidance in moral life...the normative basis of our inquiries" (2008: 13) - here we have, in tight little capsule form, the dual-role of givenist feltness-plus-guidance. One source of this reading of the PSP common between Hildebrand and Pappas is Browning 1998.

32. See Pappas $(2011: 175,179)$. 
In favoring conduct over experience, of course, the third-wave pragmatist need not deny that experience plays some role in practice. The conduct option is not anti-experience so much as it is anti-experientialism. The problems of givenism are problems that plague the history of the empiricist insistence on a global experientialism according to which all knowledge claims are dependent upon experience (suitably construed, of course $)^{33}$. In attending to those problems, we can of course accept that experience may figure locally within a practical context (even in normative practical contexts involving justification). What is important to be clear about is that such featurings of experience in practice will always be a function of local conduct (e.g., in this practice of color reporting we take first-person-singular experience as evidential) rather than an as-it-were global condition that holds for all possible practice (e.g., firstperson-singular experience is by right always evidentially privileged). Indeed, one primary gain of the conduct perspective is that it enables us to dispense with the duty of having to decide between varying forms of activity (such as experience or language) as the global criterion of practice. That which figures locally in an assemblage of practice can be accepted as figuring in just the way that it actually does figure in the conduct of that practice.

To sum up, what is needful for any contemporary classicopragmatism today is an explanation of how experientialism can avoid the helpless backslide into givenism and then from there into foundationalism. It will not do to assert that James and Dewey sought to stake out an antifoundationalist pragmatism. Of course they did and they deserve enormous praise for helping to initiate a trend that later pragmatists (Sellars, Quine, Rorty, and Brandom) could further only by standing on the ground gained by earlier classical pragmatism. But what is at issue is the extent to which James and Dewey (and their contemporary defenders) were successful at avoiding the snares of that more subtle form of foundationalism diagnosed as givenism, and indeed the extent to which they even could have been successful at that in light of their endorsement of a strong experientialist program. Such an explanation is incumbent upon contemporary classicopragmatists not only because we are today all aware of the truly colossal failings of the classical empiricist conception of experience, but also because Dewey himself finally succumbed to a frustrating awareness of the strain that any experience-centric philosophy must meet with ${ }^{34}$. My argument is that conduct pragmatism is, and on Deweyan grounds, a better option for us today than experience pragmatism. If Dewey finally admitted that he would change gears, then we should be willing to do so too. The problem is that too many contemporary classicopragmatists insist that the strain is not there and in so doing do not allow a reconstruction of

33. As I understand it, a global experientialism would involve the denial of what Huw Price has called "local expressivism" (2011: 12). Price himself endorses a "global expressivism" (2011: 11), but I see no need to go that far and in that way.

34. See Dewey's attempts at a revised preface to Experience and Nature in 1951 where he considers retitling the book Culture and Nature (LW 1: 361-2). See also Dewey's late Unmodern Philosophy and Modern Philosophy (2012) where, in early chapters, he seems prepared to abandon the experientialist analytic of his earlier work in favor of a culturalist analytic that would be more clearly antifoundationalist. On the importance of the culture concept for the mature Dewey see Goldman 2012 . 
pragmatism itself. That will not do. Dewey's misgivings cannot be wished away. What is needed is more work. We require a new composition of pragmatism.

\section{IV: The Criticism of Lingualist Pragmatism}

Another path in the history of pragmatism, and a second major branch open to contemporary pragmatism, takes its start from one version of another of the critiques of experientialism just discussed and from there takes a linguistic turn in order to recenter the pragmatist vision wholly around language, discourse, and conceptuality. The deservedly best-known representative of this strain of pragmatism is Richard Rorty, whose Sellarsian diagnoses of modern philosophy in Chapter IV of Philosophy and the Mirror of Nature are not only masterful arguments, but are also obligatory reading that need be mastered by anyone who claims to be forwarding pragmatism today ${ }^{35}$. Following on his efforts in Mirror, Rorty went on to develop in Contingency, Irony, and Solidarity and other writings a thoroughly linguistified pragmatism that brought the normative status of language use into focus by way of an idea of sociolinguistic consensus $^{36}$. For Rorty, normative correctness or rightness is always only a function of what it is right to say within a given linguistic community, a view that he famously (and provocatively) dubbed "ethnocentrism"37. Critics worried that local rightness can be no better than relativism, even if Rorty's initial point involved distinguishing relativistic nihilism from ethnocentric commitment ${ }^{38}$. Partly in response to worries that linguistic pragmatism could only fail to hold this crucial line, there soon opened up a pregnant space within neopragmatism for a thoroughly antifoundationalist version of pragmatism that would take the linguistic turn in a more systemic direction than was Rorty's wont. Herein the importance of Robert Brandom's linguistic pragmatism ${ }^{39}$.

Brandom's masterwork, the 1994 book Making it Explicit, can be read as an attempt to deliver on the promise of his Doktorvater's articulation of a thoroughly linguistic pragmatism that would rise to the challenge of accounting for practical normativity ${ }^{40}$. Brandom seeks to meet this challenge by way of a view according to which the normativity of semantic meaning is grounded in the pragmatics of what we are doing when we are speaking (or writing, or otherwise conceptualizing). At first blush, then, it may appear that Brandom is working to approximate, via the centering of pragmatics (his version of pragmatism), what I am calling conduct pragmatism. But this is not so, for Brandom is interested in what we do only insofar as speaking is often a form of acting - the only form of action that matters for Brandom is speech action. Hence Brandom's is a thoroughgoing linguistic pragmatism (or lingualism, or even a linguistic idealism) rather than a conduct pragmatism.

35. Rorty (1979: Chapter IV).

36. Rorty 1989.

37. Rorty (1985: 30$)$.

38. For two rather interesting expressions of this exceedingly common criticism see Geertz 1986, and Janack 1998.

39. One might also think of Hilary Putnam and Jürgen Habermas as having explored this space, though less under Rorty's shadow than Brandom has been.

40. Brandom 1994. 
One of the most common criticisms of Brandom's pragmatism is that his lingualism (i.e., his focus on discursiveness, which is more or less his equivalent of Rorty's idea of vocabularies) is reductive ${ }^{41}$. A related critique of Brandom's philosophy of language (but this one would not apply to Rorty) is that it furthers this reductive trend in granting primacy to assertoric over other forms of discursiveness ${ }^{42}$. But my sense is that these critiques rather miss the point. I do of course agree with the criticisms when they are pressed at a general level (yes, of course, there is more to heaven and earth than what we can speak of, and certainly more than what we can assert), but I am not really sure what is supposed to follow from these general points with respect to Brandom's case. For it seems to me that Brandom could always just reply that his aim is not to give an exhaustive ontology or a complete metaphysics. Rather, the aim might more modestly be to develop an account of only some range or subset of what a complete and exhaustive philosophy would countenance. The range or subset under focus has to do with normativity, thus illuminating a crucial connection between Brandom's project and Rorty's ${ }^{43}$. If the linguistic pragmatist can give an account of normativity without an appeal to foundations, then they seem to have discharged their self-assigned duty. The linguistic pragmatist can do this, moreover, without the insistence that "everything is normative" (and hence, conceptual and linguistic because normative). That sort of gloating globalist claim about all things under the sun is the only sort of claim that would actually open the linguistic pragmatist to the charge of reductivism. Interestingly, Brandom and Rorty have both clarified their position on the matter, in response to their critics, and explicitly claimed the more modest foci that obviate the frequent charges of reductivism ${ }^{44}$.

A more telling criticism of pragmatist lingualism than familiar chants about reductivism would be that it fails by its own lights to deliver a lingualistic explanation of normative phenomena. Indeed this is the only sort of criticism that would have any real internal bite against lingualist pragmatism. This criticism, moreover, gains real purchase when we try to understand exactly how the lingualist pragmatists position their accounts of normativity and justification. To exemplify this, I will focus here only on Brandom, leaving Rorty now to the side. I do so because Brandom's sociolinguistic account of normativity is more detailed, exhaustive, and systematic than Rorty's. I take it that if Brandom's account fails, then so too is it likely that Rorty's does, at least in those respects relevant to my argument ${ }^{45}$.

It will be useful to first outline Brandom's account. Brandom's semantics focuses, as already noted, on assertion. Brandom seeks to elucidate an assertoric semantics

41. For one example see Levine 2012. For Brandom's statements on the primacy of the linguistic see Brandom (1994: xi; 2000a: 5-7).

42. See for two examples Lance and Kukla 2010 and Taylor 2010. For Brandom's statements on the primacy of assertion in language see Brandom (1994: 173; 2000a: 10-15).

43. On Rorty's conception of justification as essentially normative (in a sense proximate to Brandom's) see Ramberg 2000 and Rorty's endorsing reply 2000.

44. See Brandom's response to Taylor 2010 where he happily concedes: "It might well be that issues of absolutely vital importance to human life can be addressed only by helping ourselves to considerations that go well beyond the rational side of our nature" (2010: 303). For Rorty's similar view see his reply (2001) to Shusterman 2001.

45. I also argue against Rorty's lingualism elsewhere in Koopman 2011. 
by grounding it in pragmatics. Brandom's key question, then, is the following: What are we doing when we assert? Brandom's answer is that we are committing ourselves to the content of that which is asserted. This commitment, on Brandom's account, is best understood in terms of the generation of a deontic status that is not reducible to a deontic attitude. In speaking, it is Brandom's argument, we institute deontic statuses, namely those of "commitments" and "entitlements" (corresponding with "the traditional deontic primitives of obligation and permission") ${ }^{46}$. In other words, we bind ourselves to what we say as well as to others who might say (or question) what we say. It is by way of the idea of a deontic status, then, that Brandom aims to philosophically account for normativity, an understanding of which he regards as "the most urgent philosophical task"47.

Brandom's account places an enormous weight upon the thin needle of an idea of deontic statuses. But when we ask what a deontic status is we run into difficulties. What are deontic statuses if not already normatively-loaded conceptualizations of our standing as assertors vis-à-vis other assertors? On Brandom's view, every assertion is normative because it generates a deontic status to which the assertor is then bound, at least until such time as they publicly revise their commitments. But, one might worry, if what we are puzzled about in the first place is normativity, then an appeal to deontic status is unlikely to help. Is this not a case of explaining the mysterious by the even more mysterious? We want to know what normativity in everyday assertoric use consists in and we are pointed toward an even more opaque form or standard of normativity in deontic status. To someone who starts out puzzled by normativity, these forays into the excesses of Kantianism are only going to make matters far worse. Likewise, someone who already has a working sense of the concept of a deontic status presumably will already understand a great deal about normativity. In short, Brandom's account appears circular. And this is a more important failing than any supposed reductivism. For a circular account is one that fails to explain. Even if the circle is virtuous rather than vicious, the problem is that anyone who finds themselves outside of the circle needs to be first brought inside of it if they are to gain any understanding at all. The philosopher cannot just point at the circle and think that doing so will magically whisk the initiate into the philosophic light. This failure of explanation is particularly problematic in Brandom's case when we recall now that the original prompt for his systematic lingualism was the widespread perception that Rorty's lingualist pragmatism flirted with relativism and so failed to evince an understanding of normativity. What Brandom's pragmatism needed to do (by Brandom's own lights) was to explain normativity. But all we are offered is a circular appeal to obligations and permissions. Presumably these were the very notions we needed an account of in the first place.

The failure of this account, I think, owes in part to the linguistic tilt that Brandom gives to his account of conduct. Brandom asserts his commitment to what he calls the "fundamental pragmatism" shared by Dewey and Heidegger, namely the thesis that

46. Brandom (1994: 159-160); for the fuller account outlined in this paragraph see (1994: Chapter 3). 47. Brandom (2009: 33). 
we should appeal to what persons $d o$ in order to explain what persons think $k^{48}$. In light of this, it might be thought that Brandom is indeed an exemplary conduct pragmatist for my purposes. In many ways he is, especially if we bear in mind my point that conduct is a thread that runs through all pragmatisms, and yet in a way that it does not receive sufficient focus. But just as Dewey's fundamental pragmatism goes astray in his being distracted by experiential quality, Brandom's gets sidetracked by a focus on linguistic commitment. This is perhaps because Brandom only appeals to conduct to explain a range of semantic and discursive issues that are his true focus. Thus he is inclined to characterize conduct purely in terms of discursive commitment. This is not only restricted (which is not the same as saying that it is reductive) but also inadequate for making sense of even the normative status of linguistic action. What Brandom should be in a better position to see is that the fundamental pragmatist strategy he has employed for addressing certain problems of semantics actually blows up the space of that problematic. What Brandom should realize is that the fundamental pragmatist is not interested in conduct only because it helps us explain linguistic meaning, but rather that conduct is of interest with respect to a fuller array of problematics such that we should be wary of construing it in lingualist terms.

\section{Conduct Pragmatism: A Third Contemporary Option}

Toward what shall pragmatism press? I have argued in previous work that the best heart of pragmatism is to be found in its focus on the transitional and transitive (the temporal and the historical) ${ }^{49}$. I want to suggest here that the third generation of pragmatism should replace the prior foci of experience and language with an undeniably transitionalist focal plane: namely, that of conduct, or action.

I noted above that a full development of conduct pragmatism requires at least two tasks. The first would involve an interpretive excavation of the idea from canonical and marginal writings in the tradition. The second would involve a philosophical development of that which has been excavated. I shall here attend primarily to the first, and then only to one aspect of the first, by taking the early William James as my precedent. What I offer is a brief explication of one seed for conduct pragmatism that we can find in the writings of the younger William James, prior to his enthusiasm for an experientialist articulation of pragmatism under the shadow of his radical empiricism and metaphysical pluralism.

There are, of course, other moments in the history of pragmatism to which we could turn for the beginnings of an elaboration of conduct pragmatism ${ }^{50}$. But I shall here focus on James, specifically the early James in the years before around 1896.

48. Brandom (2011: 9).

49. See Koopman (2009: 50-71).

50. Peirce is one obvious resource: "Intelligence does not consist in feeling in a certain way, but in acting in a certain way" (Peirce 1893 CP 6.286); see discussion by Colapietro (1989: 109) and Bernstein (1965: 79). One could also draw on elements in the early Dewey (1895: 174), the later Dewey 1922, Mead 1938, Brandom (1994: Chapter 1) and Rorty (1989: Chapter 1) - the task in each case would be to read these texts in terms of conduct pragmatism thus bringing them out from under the shadow of experientialism and lingualism. 
In these earlier writings we get a full-enough statement of conduct pragmatism that I find ripe for present development. What I thus propose is to begin third-wave pragmatism at that zero-moment of the tradition just before pragmatism received its official christening in James's 1898 California address ${ }^{51}$. To press pragmatism forward today, I am arguing, we need to go back behind "pragmatism" itself. What we gain by losing the name, in fact, is its meaning: we retrieve a perspective that focuses on action, or $\pi \rho \alpha \dot{\gamma} \mu \alpha$, or what I prefer to call, borrowing from the vernacular of nineteenth century American and English arts and letters, conduct.

One way into the conduct option is through another bit of vernacular, specifically that of the late-nineteenth century philosophical psychology in which James, Peirce, and others of their generation found themselves immersed. According to a then-standard approach, human psychology can broadly be classified according to a three-part typology of thinking, feeling, and willing. While everyone employing this typology agreed that any psychology must allow all three of these types their place, one debate that was then important, especially for the early pragmatists avant la lettre, was which of the three ought to be accorded analytic and explicative priority. Which, as Peirce would have put it, is "Third"? Which, as James himself did put it, is "department Number Three"? The subsequent history of pragmatism can be read as a development of this question. In first-wave pragmatism, the psychology of feeling came to the fore, as the emphasis is on experience, particularly the qualitative and nonratiocinative experience at the heart of Dewey's postulate of immediate empiricism and James's radical empiricist flux ${ }^{52}$. In second-wave pragmatism, the psychology of thinking comes to the fore and the emphasis is on conceptuality, often understood in terms of discursive capacities, as evidenced in both Rorty's linguistic pragmatism and Brandom's self-titled rationalist pragmatism ${ }^{53}$. If, as I have argued above, we meet with certain long-standing (though perhaps one day negotiable) impasses with first-wave "feeling pragmatism" and second-wave "thinking pragmatism", then it is time that we give third-wave "willing pragmatism" its inning. This means trying out pragmatism as conduct pragmatism.

Given the later James's emphasis on experience, it is often assumed that his lifelong philosophical answer to the crucial question concerning "department Number Three" would have been feeling, or experience. James's pragmatism, we are told time and time again, was a pragmatism of experience. In the face of this common wisdom, it is jarring then, to read Peirce's criticisms of his longtime friend James in the former's entry under "Pragmatism" in Mark Baldwin's 1902 "century" Dictionary of Psychology and Philosophy:

51. James 1898

52. I do not hold that feeling is in fact identical with experience, but rather that experiential pragmatism is primarily a pragmatism of "feeling" in the latter-nineteenth century sense of that term. This is born by a rereading of the emphasis on the "feltness" of experience that pervades the writings of both James (1910) and Dewey (see citations above).

53. Again, my point is not that thinking is in fact synonymous with conceptuality, but rather that a typology that is able to distinguish thinking, feeling, and willing will tend to align the first term with rationality, conceptuality, and discursive whilst aligning the second term with experience and quality. On the rational nature of the conceptual see for instance Brandom (1994: Chapter 3) elsewhere explicitly framed as a version of "rationalist pragmatism" (2000a). 
In 1896 William James published his Will to Believe, and later his Philos. Conceptions and Pract. Results, which pushed this method to such extremes as must tend to give us pause. The doctrine appears to assume that the end of man is action - a stoical axiom which, to the present writer at the age of sixty, does not recommend itself so forcibly as it did at thirty. If it be admitted, on the contrary, that action wants an end, and that that end must be something of a general description, then the spirit of the maxim itself, which is that we must look to the upshot of our concepts in order rightly to apprehend them, would direct us towards something different from practical facts, namely, to general ideas, as the true interpreters of our thought. ${ }^{54}$

Peirce here attributes to James a view which he admits that he, Peirce, had endorsed as a younger man (of thirty), but which he has since (now being sixty) seen beyond, while James apparently remains beholden to it.

Consider now James on Peirce in that 1898 "Philosophical Conceptions and Practical Results" address in California that is generally view as the official inauguration of "pragmatism". James there attributes to Peirce this view:

The same thought may be clad in different words; but if the different words suggest no different conduct, they are mere outer accretions, and have no part in the thought's meaning. ${ }^{55}$

Continuing, James tells us that he himself will interpret pragmatism "more broadly" than Peirce:

The ultimate test for us of what a truth means is indeed the conduct it dictates or inspires. But it inspires that conduct because it first foretells some particular turn to our experience which shall call just that conduct from us. ${ }^{56}$

All of this requires some explanation. Where are we?

In 1902 Peirce attributed conduct pragmatism to James (and his own younger self), and criticized that view, preferring to place conduct in the service of thinking ("general ideas"). But already by 1898 James had attributed conduct pragmatism to Peirce, himself putting conduct in the service of what is qualitatively felt ("some particular turn to our experience"). Peirce's 1902 objections to James thus seem to be aimed at a position that James himself hardly seemed to hold. Peirce was, to be sure, in part distancing himself from the view James had imputed to him. But Peirce, both in print and in correspondence, continued to press the objection as an objection not against his younger self so much as against James ${ }^{57}$. Why? Did James ever even hold the view that conduct is, as Peirce had put it, both in public print and in private correspondence to James, "the be-all and the end-all"58? Did Peirce himself ever hold that view in any serious way? Who, if anyone, ever really held the view such that

54. Peirce (1902: 322).

55. James (1898: 348).

56. James (1898: 348).

57. See Peirce 1907 EP 2: 401 (in Variant 1) and EP 2: 432 (in Variant 2); Peirce to James, Jan. 23 , 1905 in CWJ 10: 535

58. Peirce (1905: 341); see also Peirce to James, Nov. 25, 1902 in CWJ 10: 157. 
Peirce felt the need to continually refute it and James so frequently sought to distance himself from it?

In his later writings, at least, James increasingly dedicated himself to a version of experience pragmatism. Experience, especially in the shape of radically empiricist experience, is all over the Essays in Radical Empiricism (published posthumously in 1912, but developed most fully in two essays of 1904 and 1905), A Pluralistic Universe (published in 1910), and much (but certainly not all) of Pragmatism (published in 1907) too. All of these texts were written under the shadow of a radical empiricism in the service of experience ${ }^{59}$. And already in his 1898 essay James puts conduct in the service of experience. Had Peirce missed his target altogether? Had James ever really endorsed a pragmatism centered on conduct rather than experience?

Yes, he had, and decidedly so. If we turn back to James's works before his radical empiricist period, namely those of his writings up until around 1897 or so, we find rich resources for developing pragmatism along the lines of a conduct pragmatism. In turning back to James's writings where an emphasis on willing and conduct is marked, we can show not only that Peirce's criticisms of James in 1902 were aiming at a real target (because James did officially forward a version of conduct pragmatism in earlier writings), but also that the target itself may be more interesting than Peirce's criticisms, and James's later abandonment, seem to have suggested.

The view I shall be tracking is one that James expressed in a letter to his younger brother Robertson in 1876: "My 'dying words' to you are, 'outward acts, not feelings'!" 60 . James, it would turn out, did not die with these words, trading in conduct for feeling almost twenty years later. These are, nevertheless, among some of James's most fecund words for pragmatists today. Their further development in his early published writings gives the contemporary conduct pragmatist much from which to glean.

In his 1884 essay "The Dilemma of Determinism” James confronted that twain issuance of the late nineteenth century described by Hacking as the parallel tendencies of the taming of chance and the erosion of determinism ${ }^{61}$. The essay is devoted to one of the centermost preoccupations of all of James's philosophizing: freedom. James's tactic in the essay is not that of mounting a refutation of determinism and a defense of voluntarism. Rather he seeks to mount a moral defense of chance against determinism's denial of its very possibility. But where is chance located? And where

59. My claim is not that James's later works were not all-experience and no-conduct. My point rather concerns their relative weight. Consider, for instance, James's claim in the "Preface" to Pragmatism that "there is no logical connection between pragmatism [...] and a doctrine [...] set forth as "radical empiricism"" (1907: 6). This noted, consider also that in the "Preface" to The Meaning of Truth: A Sequel to "Pragmatism" James is already pushing for a tighter connection in saying that "the establishment of the pragmatist theory of truth is a step of first-rate importance in making radical empiricism prevail" (1909: 172). These two prefatory remarks are not inconsistent, though they do tend to push in different directions. I am in fullest agreement with James when he says, in the earlier text, that "one may entirely reject [radical empiricism] and still be a pragmatist" (1907: 6). I see myself as here following up on that suggestion and so my mantra is: "let us be action-oriented pragmatists without having to be metaphysicians of experience".

60. James CWJ 4: 586.

61. See Hacking 1990. 
would determinism deny its possibility? For James in 1884, the terrain of freedom is not to be located in argumentative reason, nor even in felt sensation (where he would come to locate it later), but rather in action. The possibility of freedom that James defends throughout his early writings is a possibility of enacting freedom, and it is in his early writings that he is most explicit that it is on the plane of action where determinism's denials are at their most demoralizing. This helps explain why all of James's early defenses of freedom are explicitly articulated on a moral register, and why on every occasion he explicitly disclaims a metaphysical defense of freedom according to which freedom can be proven ${ }^{62}$. Freedom was for James always primarily a moral and not a metaphysical category, and thus it is something that must, if it is to exist, be enacted, perhaps even composed. James thus wrote in his 1884 essay, embracing Carlyle's philosophy of work, that "conduct, and not sensibility, is the ultimate fact for our recognition"63. Such recognitions of conduct are, it turns out, pervasive in James's early writings. They not only center his moral writings on freedom, but as well his early and monumental contributions to psychology, also articulated in an explicitly non-metaphysical register.

James's published his monstrous magnum opus in 1890, claiming that it was "in irreproachable shape" by the time it was finally delivered to the publisher nearly one decade later than originally promised ${ }^{64}$. Jacques Barzun, almost one hundred years hence, would find it instead "a masterpiece in the classic and total sense" ${ }^{65}$. The Principles of Psychology begins on the first page by defining the scope of its subject matter: "Psychology is the Science of Mental Life, both of its phenomena and their conditions" ${ }^{\prime 6}$. Though James focused his work on the mental life, the entire book would be radically misconstrued if situated as another contribution to that long line of philosophies of consciousness. James's concept of mind is of mentality emplaced, embodied, and above all enacted. For James, in fact, the mind is defined as a form of action. Mindedness is not a form of awareness (sentience) or cogitation (sapience), though it may involve that as part of its work. Mind for James is a form of action whereby the pursuit of ends is carried out with variation in means: "The pursuance of future ends and the choice of means for their attainment are thus the mark and criterion of the presence of mentality" 67 . James offers the memorable example of a frog in an aquarium. We place an inverted jar full of water above our frog presently resting at the bottom of the tank. We wait and the amphibian soon in want of breath will begin its journey upward toward the surface. But if frog proceeds upward into the jar we have placed above it will find itself impeded and then, in the crucial display of mindedness, "will restlessly explore the neighborhood" until it finds a path to the surface $^{68}$. Contrast frog to your floatable rubber ducky released from the same bottom

62. James (1884: 588; 1890 II: 569-579) are two instances; for a much earlier autobiographical note to this effect see James (1870: 7).

63. James (1884: 604).

64. James in CWJ 7: 35

65. Barzun (1983: 34).

66. James (1890 I: 1).

67. James (1890 I: 8)

68. James (1890 I: 7) 
of the tank upward into the same inverted jar. Your ducky will forever press its nose up against the glass. Little ducky would go further could it do so, but unlike frog it cannot vary its means toward the achievement of its fixed ends. Our friend frog is minded but ducky has no mind at all. James continues, explicitly defining the quality of mind in these terms as a species of action: "no actions but such as are done for an end, and show a choice of means, can be called indubitable expressions of Mind" 69 . James, almost mocking Cartesian consciousness, remasters the classical concept of mind by locating it in action. For Descartes, mind was still and silent, sitting by the fire, unmoving and calm, meditative. Mind becomes reason, thoroughly aware of itself. For James, by contrast, mind is typified by the active creature who is creative in pursuing its ends in its environments. Mind becomes movement conducting otherwise dead matter.

Having thus specified the mind in chapter I, James turns in chapter II to the brain, which he introduces through a brief discussion of the concept of reflex action. Here he claims that "reflex and voluntary performances shade into each other gradually" thereby foreshadowing the later culminating claims of the book in the long chapter XXVI on the will. The discussion of reflex action in the early chapter of the Principles is surprisingly brief. But James's 1881 essay "Reflex Action and Theism" offers an extended development of the idea. Interestingly, this is also the essay in which can be found James's first public, though not quite yet official, reference to pragmatism, namely Peirce's pragmatism as laid out in the 1878 Popular Science Monthly essays of a few years previous ${ }^{70}$. James writes that "it may be said that if two apparently different definitions of the reality before us should have identical consequences, those two definitions would really be identical definitions, made delusively to appear different merely by the different verbiage in which they are expressed", footnoting Peirce's article in which the pragmatic maxim was first announced as explanans ${ }^{71}$. James's essay itself is not specifically devoted to pragmatism, but taking note of the quotation and footnote is helpful, for it motivates my more general claim that James was long a pragmatist before officially announcing himself to be such in his 1898 California lecture.

If James was indeed already a pragmatist of any variety in 1881, he was a pragmatist of the conduct stripe. Referring to the reflex arc concept with high praise as the "great achievement of our generation" James addresses himself in the essay to tracing its consequences, specifically for religion, and for religious belief. It is not so much the implications that concern us here as James's stylization of the reflex arc idea: "The current of life which runs in at our eyes or ears is meant to run out at our hands, feet, or lips [...]. The willing department of our nature, in short, dominates both the conceiving department and the feeling department; or, in plainer English, perception and thinking are only there for behavior's sake" 72 . Here we have the three key terms of a quintessential triad for pragmatism and a general typology in late

69. James (1890 I: 11).

70. See especially Peirce 1878.

71. James (1881: 124).

72. James (1881: 114). 
nineteenth century psychology ${ }^{73}$. What matters philosophically is that each term in the triad offers a different point of emphasis in how to interpret the upshot of Peirce's pragmatic maxim.

Quality, Thought, Action. Feeling, Conceiving, Willing. Experience, Language, Conduct. How should the pragmatist prioritize among these? Peirce seems to have often held Thought as Third. James, later in life, seemed to hold Feeling as Third, as Dewey would too in developing his qualitative pragmatism. But here, in 1881, James is unequivocal: Conduct is Third. It is Action, Habit, and Will that form the assemblage assuming the privileged place of what he calls "department Number Three" that "ever lurks in ambush, ready to assert its rights" $"$. James's view is unambiguously stated: "Transformation is effected in the interests of our volitional nature, and for no other purpose whatsoever"75. In another short essay of 1882, which James quoted from at length in Principles, he concurs: "It is far too little recognized how entirely the intellect is built up out of practical interests [...]. Cognition, in short, is incomplete until discharged in act"'76. Later on, in an 1888 Scribner's article also selectively requoted in Principles, James states: "the thinking and feeling portions of our life seem little more than half-way houses towards behavior; and recent Psychology accordingly tends to treat consciousness more and more as if it existed only for the sake of the conduct which it seems to introduce, and tries to explain its peculiarities (so far as they can be explained at all) by their practical utility" "77. None of this is to insinuate that for the early James there is no room for feeling or thinking. The claim is only about what takes priority: what is in the service of what: what is central and what is remainder in the pragmatist perspective. For all pragmatists, all three departments are crucial. But one department must lead and coordinate, even if only to provide a semblance of methodological priority. For James in his early work, conduct was crown.

Why, it might be wondered, force ourselves to choose ${ }^{78}$ It might be objected that we can and should adopt a meta-pragmatist stance toward pragmatism itself. This might involve allowing ourselves to decide which of the three options (experience, language, and conduct) to prioritize on the basis of an analysis of the practice in question. The objection is important because it calls into question my emphasis on the need to prioritize amongst the three categories. But in defense of prioritization I hold that deferring the issue can only lead us back to the very same question all over again. We cannot defer analytic prioritization by way of waiting upon an analysis of whatever practice is in question. This is because what is at issue is precisely how one

73. On the widespread (and quite varying) uses of this triad in late nineteenth century psychology see Bordogna (2008: 148 ff.).

74. James (1881: 127).

75. James (1881: 117).

76. James (1882b: 65-66) quoted in James (1890 II: 314), and in (1882a: 84); see also (1890 II: 372 ).

77. James (1888: 240).

78. For instance, Francesca Bordogna's interpretation of James's relation to the triad is representative in that she reads James as undermining the traditional separation between the three (2008: 151). I contend that James found methodological value in separation such that he sought to keep the distinction usable in order that we might focus on different points of the triad playing the leading role. It is my view that James (both later and younger) sought to make use of the distinction (differing with himself only over which of the three departments would lead, but not over whether some one department must so lead). 
is to pragmatically specify what counts as the practice in question. A reference to practice cannot settle the issue of prioritization because what is at issue are the very terms according to which we are going to refer to practice. At issue, in other words, is a central (perhaps the central) methodological question of pragmatism: What is the leading index for the "practical starting point" that is the focus of every pragmatism? Which of experience, language, or conduct gives us the best methodological grip on practice itself? This is an issue that cannot, for reasons of regress, be settled by an appeal to practice itself ${ }^{79}$.

This position is not mine alone. James and Peirce both held that the prioritization question could not be shoved to the side. The younger James resolved the question in favor of conduct. And so Peirce's arrows in 1902 were rightly aimed. The 1881 article at which they were aimed was by then twenty years past, it is true, but undoubtedly James had made his views known to Peirce time again in personal conversation, not to mention in correspondence, not to mention quoting and re-quoting said view in his series of psychology books, as well as in other writings. James and Peirce were two longtime friends unlikely to foist misunderstandings on one another. Their minds were on the most intimate of terms. James had held the view that Peirce criticized him for holding, even if he had largely abandoned it in large by the time the criticism was finally foisted.

Of course, James never fully abandoned the emphasis on conduct, as noted by Sergio Franzese's recent treatise on Jamesian energy ${ }^{80}$. In turning to James in the service of developing a conception of conduct, the early James will be the first place to turn $^{81}$. But the second place to consider will be a number of later writings where James continues, if only on occasion, to emphasize action ${ }^{82}$. One obvious source would be James's 1896 offering "The Will to Believe" whose central problem throughout is a problem of action and specifically of acting in the face of chance (but only chance) ${ }^{83}$.

79. I thank both David Rondel and Alexis Dianda for pressing me on points in this paragraph.

80. I endorse at a broad level Franzese's claim that, "The view of humans as 'indeterminate' beings hinges on James's notion of primacy of action" (2008: 5), but I depart from his attempt to read this notion quite broadly in James's later writings (105 ff.) on the basis of an excavation of the idea in earlier work (99 ff.). I wish Franzese were right, but I cannot but lament that James's later writings so often cede the primacy of action for the sake of the prioritization of experience. My worry vis- $\dot{a}$-vis Franzese, then, is that we must always be careful to distinguish the two analytically distinct notions of conduct and experience.

81. However, just as the later James was not all-experience and no-action, the earlier James was not all-action and no-experience, as even just a quick skim of the Principles (1890) will show. As noted previously, my argument only concerns the relative weights assumed by these notions in different periods of James's career.

82. Even in the central writings of James's radical empiricist project, there is a continuing role for action to play; see James (1904a: 181; 1904b: 201).

83. It may be thought that the publication date of "The Will to Believe" calls into question my emphasis on a divide in James's thinking around the year 1896. This is the occasion to emphasize that I do not require for my argument either a sudden or a total break in James's work. I only mean to point out a decided shift in emphasis. With that in mind, it bears noting that the problematic of "The Will to Believe" is one that James had long been working through, despite the seemingly hurried composition of the text in 1896, as noted by Gavin $(2013: 4,43,55,91)$ and discussed by Hollinger (1997) and others. As early as 1879 James published a review of two of Clifford's works in The Nation (1879) focusing on exactly the position that he would later attribute to Clifford in 1896 and then seek to dismantle. On the other end, that James never lost sight of interest in these questions (and thus questioning any idea of a "total" 
The point of "The Will to Believe" is that not only do we meet with real situations of indeterminacy where we find ourselves confronting our own hesitation against action, but that further these indeterminacies need not be taken as burdens which we cannot bear. We could bear them, James is arguing, if only we are willing to act anyway. We can thereby, through conduct, even a stuttering conduct, possibly determine the indeterminate ${ }^{84}$. And we can do so in a way that would work through indeterminacy rather than annul it. This is to treat indeterminacy as a possibility and opportunity for the vita activa, rather than to cast it in terms of debilitating doubt that must be banished from the res cogitans. A crucial point on which James's "Will to Believe" focuses, then, is a strident emphasis on the centrality of willing for our active living. As I argue elsewhere, James's "Will to Believe" cannot be made sense of without situating it within the conceptual constellation adumbrated in the "Will" chapter of the Principles only six years early ${ }^{85}$. That conceptual constellation, as we have seen, figures the will in terms of conduct and action.

From 1881 to 1890 to 1896 , James's philosophical focus yielded a true pragmataism where human conduct was the center of analytic attention. Anthropologist Elizabeth Povinelli (in a recent article on Foucault and James on the will) offers a compelling summary statement of the conduct-centered quality of Jamesian psychology: "Minds qua minds, as well as particular minds and their mental contents, were the result of an embodied history of effort and exhaustion, striving and succeeding, striving and failing, and doing so in a socially differentiated world"86. Following these (and other, for there are many more passages from which to select, to be sure) early elaborations of a conduct-centered pragmatism, there then came a fairly major shift in James's thinking in the years leading up to and following 1896. That there was such a shift has been well documented by previous scholars ${ }^{87}$. And yet the specific terms of this shift, as one that took James out from his habitation in a conduct-centered methodology, have not been frequently observed. Too many have looked forward out of the shift toward experience pragmatism. I am encouraging that we look back behind it. For prior to his change of attitude, James can be seen, as his most able reader, Charles Santiago Peirce, noted in criticisms both public and private, a conduct pragmatist.

\section{VI: The Conduct Option}

Language and experience both matter to philosophy, but their matter carries less gravity than does action. Consider in conclusion two key methodological gains of pragmatism. One is an emphasis on transitionality, or temporality and historicity.

break between the conduct pragmatism prominent in the early James and the experientialism prominent in the later James) is evidenced by his later revisions of the will to believe argument in his "Faith and the Right to Believe" fragment (1910b).

84. I borrow the notion of the stutter from Alexander Livingston's (2013) excellent essay on the Jamesian will.

85. See Koopman (unpublished-b).

86. Povinelli (2012: 465).

87. See for instance discussions by McDermott 1977, Seigfried 1990, Lamberth 1999, and Bordogna 2008. A common refrain (which I here repeat, though with an eye toward a different result) is that 1896 was the year in which James first announced radical empiricism (1896b: vii). 
The other is an emphasis on the relay between problematizations and reconstructions as the site where normativity, and much else too, would unfold. Packaging these two together, we can recognize that the great gain of pragmatism is that it proposes an account of normativity framed in terms of the transitional processes whereby we reconstruct problematic situations. Pragmatism thus proposes to both countenance normativity and do so without invoking foundations - thus fulfilling what I described above as the twain desiderata of normativity without foundations or authority without authoritarianism.

How does conduct fair as a methodological category that leverages pragmatism's twin insights of a transitional focus and a problematic method? There is no need to pretend that I could decisively answer this question here. But allow me to conclude with some suggestions.

First, conduct is, as already noted above, an inherently dynamic notion. Conduct is, in every instance, in motion. Conduct is pre-eminently a doing rather than a thing done. The conduct option is thus so attractive because it points directly (not merely indirectly as is the case with the other two offerings) to the centrality of historicity and temporality at the heart of pragmatism. Though prior pragmatisms may have worked toward accounts of language and experience as dynamic in character, it is undeniable that thinking and feeling admit of static treatment in a way that conduct simply does not. A doing is something that moves, while meaning has for us almost entirely lost its verbal sense, and experiencing is already an awkward construct in contrast to an experience. Conduct is unavoidably processual.

Second, it is my bid that the ineluctably transitional quality of action or conduct that best facilitates pragmatist attention to normative reconstruction or melioration. If the core of pragmatism in each of its successive waves is the idea of transitions from a problematic or indeterminate beginning to an unproblematic or determinate ending, then action or conduct offers a register on which we can specify reconstruction in just those terms. For what matters most when we come up against the press of a problem or compose a reconstructive response is the hesitation or action at issue. Although feeling and thinking may serve as proxies here, what they are proxies for, and what they are therefore in the service of, is conduct. We might then say that pragmatism is the philosophy that affirms the import of experience and language by locating them within the field of conduct in which human lives are leadings to and fro $^{88}$.

88. For comments on earlier drafts of this paper I thank David Rondel, Stéphane Madelrieux, two anonymous reviewers, David Hildebrand, and an audience at the New School for Social Research (including Ramón del Castillo, Alexis Dianda, Paul Grimstad, and Josh Kaye). 


\section{References}

Barzun J., (1983), A Stroll with William James, Chicago: University of Chicago Press.

Beisecker D., (Unpublished), "Affirming Denial: Peirce and Brandom on an Alleged Blindspot of Classical Pragmatism", paper presented at the Society for the Advancement of American Philosophy Annual Meeting, 2013.

Bernstein R. J., (1965), "Action, Conduct, and Self-Control”, in Perspectives on Peirce: Critical Essays on Charles Saunders Peirce, ed. by R. J. Bernsstein, New Haven: Yale Univerisity Press.

— (2007), "Hegel and Pragmatism”, in Bernstein 2010.

— (2010), The Pragmatic Turn, Cambridge: Polity Press.

Bordogna F., (2008), William James at the Boundaries: Philosophy, Science, and the Geography of Knowledge, Chicago: University of Chicago Press.

Brandom R., (1994), Making it Explicit: Reasoning, Representing, and Discursive Commitment, Cambridge: Harvard University Press.

- (2000a), Articulating Reasons: An Introduction to Inferentialism, Cambridge: Harvard University Press.

— (2000b), "Analyzing Pragmatism: Pragmatics and Pragmatisms", reprinted in Brandom 2011.

- (2004), "Classical American Pragmatism: The Pragmatist Enlightenment - and Its Problematic Semantics", reprinted in Brandom 2011.

- (2009), Reason in Philosophy: Animating Ideas, Cambridge: Harvard University Press.

- (2010), "Responses", in Reading Brandom: On Making It Explicit, ed. by B. Weiss and J. Wanderer, New York: Routledge.

—(2011), "From German Idealism to American Pragmatism - and Back", introduction to Brandom 2011.

— (2011), Perspectives on Pragmatism, Cambridge: Harvard University Press.

Browning D., (1998), "Dewey and Ortega on the Starting Point", Transactions of the Charles S. Peirce Society, XXXIV, 1, 69-92. 
Burke F. T., (2013), What Pragmatism Was, Bloomington: Indiana University Press.

Colapietro V., (1989), Peirce's Approach to the Self: A Semiotic Perspective on Human Subjectivity, Albany: SUNY Press.

Dewey J., (1895), “The Theory of Emotion, II", in EW 4, Carbondale: Southern Illinois University Press, 2008.

- (1903), “The Relation of Thought and Its Subject-Matter" in Essays in Experimental Logic [1916], New York: Dover, 2004.

- (1922), Human Nature and Conduct, in MW 14, Carbondale: Southern Illinois University Press, 1983.

- (1925), Experience and Nature, in LW 1, Carbondale: Southern Illinois University Press, 1983.

- (1929), The Quest for Certainty, in LW 4, Carbondale: Southern Illinois University Press, 1988.

- (1930), “On Qualitative Thought”, in LW 5, Carbondale: Southern Illinois University Press, 1985.

- (1938), Logic: The Theory of Inquiry, in LW 12, Carbondale: Southern Illinois University Press, 1991.

- (1941), "Propositions, Warranted Assertibility, and Truth", in LW 14, Carbondale: Southern Illinois University Press, 1988.

- (1951), "The Unfinished Introduction", appendix to Experience and Nature, in LW 1, Carbondale: Southern Illinois University Press, 1981.

- (2012), Unmodern Philosophy and Modern Philosophy, ed. by Phillip Deen, Carbondale: Southern Illinois University Press.

Franzese S., (2008), The Ethics of Energy: William James's Moral Philosophy in Focus, Piscataway: Transaction Books.

Gavin W., (2013), William James in Focus: Willing to Believe, Bloomington: Indiana University Press.

Geertz C., (1986), “The Uses of Diversity”, Michigan Quarterly Review 25, 1, 105-123. 
Goldman L., (2012), "Dewey's Pragmatism from an Anthropological Point of View", Transactions of the Charles S. Peirce Society, 48, 1, 1-30.

Grimstad P., (2013), Experience and Experimental Writing: Literary Pragmatism from Emerson to the Jameses, New York: Oxford University Press.

Hickman L., (2007), "Some Strange Things they Say about Pragmatism: Robert Brandom on the Pragmatists' Semantic 'Mistake'”, Cognition, 8, 1, 105-113.

Hildebrand D., (2003), Beyond Realism and Antirealism: John Dewey and the Neopragmatists, Nashville: Vanderbilt University Press.

- (2011), “Could Experience Be More than a Method?: Dewey's Practical Starting Point”, in Pragmatist Epistemologies, ed. by Roberto Frega, Lanham: Lexington.

Hildebrand D., and Pappas G., (2010), "Review of Pragmatism as Transition", Notre Dame Philosophical Reviews, 2010.08.29, online at http://ndpr.nd.edu/news/24466pragmatism-as-transition-historicity-and-hope-in-james-dewey-and-rorty/.

Hollinger D., (1997), "James, Clifford, and the Scientific Conscience", in The Cambridge Companion to William James, ed. by Ruth Anna Putnam, Cambridge: Cambridge University Press.

James W., (1870), “April 30, 1870”, diary entry in WWJ.

— (1881), "Reflex Action and Theism", in WTB.

— (1884), “The Dilemma of Determinism”, in WWJ.

— (1888), "What the Will Effects", Scribner's Magazine, 3, 2, 240-250.

- (1890), The Principles of Psychology, Dover: New York, 1950.

— (1898), "Philosophical Conceptions and Practical Results", in WWJ.

- (1879), "Lectures and Essays and Seeing and Thinking by W. K. Clifford (1879)", Essays, Comments, and Reviews, Cambridge: Harvard University Press, 1987.

— (1882a), “The Sentiment of Rationality”, in WTB.

- (1882b), "Rationality, Activity, and Faith", The Princeton Review, 58, 1, 58-86.

- (WTB), (1986), The Will to Believe and Other Essays, New York: Dover Publications, 1956. 
James W., (1986), "Preface” to James, in WTB.

— (1904a), "Does Consciousness Exist?”, in WWJ.

— (1904b), “A World of Pure Experience”, in WWJ.

— (1907), Pragmatism, in P\&MT.

— (1909), The Meaning of Truth, in P\&MT.

— (1910), A Pluralistic Universe, in WWJ.

— (1910b), "Faith and the Right to Believe", in WWJ.

— (WWJ), (1977), The Writings of William James, ed. by J. J. McDermott, Chicago: University of Chicago Press.

- (P\&MT), (1909), Pragmatism and The Meaning of Truth, Cambridge: Harvard University Press, 1975.

- (CWJ), (1992-2004), The Correspondence of William James, Charlottesville: University of Virginia Press.

Janack M., (1998), "Rorty on Ethnocentrism and Exclusion", The Journal of Speculative Philosophy, 12, 3, 204-216.

Johnson M., (2007), The Meaning of the Body: Aesthetics of Human Understanding, Chicago: University of Chicago Press.

- (2014), Morality for Humans: Ethical Understanding from the Perspective of Cognitive Science, Chicago: University of Chicago Press.

Koopman C., (2007), "Language is a Form of Experience: Reconciling Classical Pragmatism and Neopragmatism", Transactions of the Charles S. Peirce Society, $43,4,694-727$.

- (2009), Pragmatism as Transition: Historicity and Hope in James, Dewey, and Rorty, New York: Columbia University Press.

- (2011), “Rorty's Linguistic Turn: Why (More Than) Language Matters to Philosophy", in Contemporary Pragmatism, 8, 1, 61-84. 
Koopman C., (unpublished-a), "The Taming of Chance and Transforming of Self: William James on 'Our Undisciplinables'".

— (unpublished-b), "The Will, the Will to Believe, and William James".

Lambertt D., (1999), William James and the Metaphysics of Experience, Cambridge: Cambridge University Press.

Lance M., and Kukla R., (2010), "Perception, Language, and the First Person", in Reading Brandom: On Making It Explicit, ed. by B. Weiss, and J. Wanderer, New York: Routledge.

Levine S., (2012), "Brandom's Pragmatism”, Transactions of the Charles S. Peirce Society, 48, 2, 125-140.

Livingston A., (2013), "Stuttering Conviction: Commitment and Hesitation in William James' Oration to Robert Gould Shaw", Contemporary Political Theory, $12,4,255-276$.

Madelrieux S., (2012), “Action as Philosophic Method", presented at the European Pragmatism Conference, September 2012, available online at [http://www. nordprag.org/papers/epc1/Madelrieux.pdf].

Marchetti S., (2012), "Theory and Practice of Conduct in James" presented at the European Pragmatism Conference, September 2012, available online at [http:// www.nordprag.org/papers/epc1/Marchetti.pdf].

Mead G.H., (1938), The Philosophy of the Act, ed. by Charles W. Morris, Chicago: University of Chicago Press.

McDermott J. J., (1977), "Person, Process, and the Risk of Belief”, in WWJ.

Misak C., (2013), The American Pragmatists, Oxford: Oxford University Press.

Pappas G. F., (2011), “The Latino Character of American Pragmatism”, in Pragmatism in the Americas, ed. by G. F. Pappas, New York: Fordham University Press.

- (2008), John Dewey's Ethics: Democracy as Experience, Bloomington: Indiana University Press.

Peirce C. S., (1878), "How to Make Our Ideas Clear", in The Essential Peirce, volume 1: 1867-1893, Bloomington: Indiana University Press, 1992. 
Peirce C.S., (CP), (1893), "The Materialistic Aspect of Reasoning", in Collected Papers 6, Cambridge, Harvard University Press, 1935.

- (1902), "Pragmatic and Pragmatism", in Dictionary of Philosophy and Psychology, volume 2, ed. by M. Baldwin, New York: Macmillan.

- (1905), "What Pragmatism Is", in The Essential Peirce, volume 2: 1893-1913, Bloomington: Indiana University Press, 1998.

- (1907), "Pragmatism", unpublished article sent to Nation and Atlantic Monthly, reprinted in The Essential Peirce, volume 2: 1893-1913, Bloomington: Indiana University Press, 1998.

Povinelli E. A., (2012), "The Will to be Otherwise/The Effort of Endurance", South Atlantic Quarterly, 111, 3, 453-475.

Price H., (2011), Naturalism without Mirrors, Oxford: Oxford University Press.

Putnam H., (2002), “Comment on Robert Brandom's Paper", in Hilary Putnam: Pragmatism and Realism, ed. by U.M. Zeglen, and J. Conant, London: Taylor and Francis.

Ralston S., (2013), “Taking Experiential Givenism Seriously”, SAGE Open, JulySept. 1-9.

Ramberg B., (2000), "Post-Ontological Philosophy of Mind: Rorty versus Davidson", in Rorty and His Critics, ed. by R. Brandom, Oxford: Blackwell.

Rorty R., (1977), "Dewey's Metaphysics", in Consequences of Pragmatism. Minneapolis: University of Minnesota, 1982.

- (1979), Philosophy and the Mirror of Nature. Princeton: Princeton University Press.

— (1985), "Solidarity or Objectivity?", in Objectivity, Relativism, and Truth: Philosophical Papers Volume 1, Cambridge: Cambridge University Press, 1991.

- (1989), Contingency, Irony, and Solidarity, Cambridge: Cambridge University Press.

- (1992), "Dewey Between Hegel and Darwin", in Truth and Progress: Philosophical Papers, Volume 3, Cambridge, Cambridge University Press, 1998. 
Rorty R., (2000), “Response to Ramberg”, in Rorty and His Critics, ed. by R. Brandom, Oxford: Blackwell.

- (2001), "Response to Richard Shusterman", in Richard Rorty: Critical Dialogues, ed. by M. Festenstein, and S. Thompson, Cambridge: Polity.

Russell B., (1940), An Inquiry into Meaning and Truth, London: Routledge, 1992.

Seigfried C. H, (1990), William James's Radical Reconstruction of Philosophy, Albany: SUNY Press.

Shusterman R., (2000), Pragmatist Aesthetics: Living Beauty, Rethinking Art, Lanham: Rowman and Littlefield, $2^{\text {nd }}$ ed.

- (2001), "Reason and Aesthetics Between Modernity and Postmodernity: Habermas and Rorty", in Richard Rorty: Critical Dialogues, M. Festenstein, and S. Thompson, Cambridge: Polity.

Taylor C., (2010), “Language Not Mysterious?”, in Reading Brandom: On Making It Explicit, ed. by B. Weiss, and J. Wanderer, New York: Routledge. 